\title{
USING ENVIRONMENTAL ISSUES TO TRIGGER THE STUDENTS' CRITICAL THINKING IN ESSAY WRITING CLASS
}

\author{
Lestari Setyowati \\ STKIP PGRI Pasuruan \\ lestari.setyowati@yahoo.co.id \\ Sony Sukmawan \\ Universitas Brawijaya \\ sony_sukmawan@ub.ac.id
}

\author{
Ana Ahsana El-Sulukiyyah \\ STKIP PGRI Pasuruan \\ aahsana3@gmail.com
}

\begin{abstract}
The advancement of technology and information in this 21 st century brings heavy consequences on the environment. Therefore, the young generation needs to be introduced and educated about the environmental issues so that they become an active agent in environmental protection. The use of environmental issues in the language classroom offers wide opportunity for the students to think and respond critically to the environmental problem. This paper is intended to describe the students' ability in writing an essay by using an environmental topic about the use of water. The design of the study is content analysis design. The sujects of the study were 32 students of 2017 batch taking essay writing course in the academic year 2018-2019. The instrument used was mainly documentation. The result of the study showed that almost two thirds $(72 \%)$ of the students were able to state a thesis statement. The majority of the students $(88 \%)$ were able to give elaboration and explanation in the body of the essay, but $66 \%$ of them failed to give details and examples. Most of the students developed the essay by using cause and effect, problem solution, and reasoning paragraph organization. Not all students were able to write a proper conclusion for the essay. The conclusions written by the students mostly contained advice $(62 \%)$ of what others should do to preserve nature.
\end{abstract}

Keywords: Environmental Issues, Environmental Education,

Essay Writing, Critical Thinking

\section{INTRODUCTION}

The world today has suffered from severe environmental problems. Global warming, draught, flood, landslides, and pollution are only some examples of the environmental problems which appear almost every day in the news. These environmental problems happen because of human's unfriendly behavior toward nature, such as illegal logging, polluting river, land conversion, and excessive use of water. Because of these, it is becoming urgent to raise people's environmental awareness so that they can appreciate nature better.

Education has an important role in facilitating the younger generations to be better citizens in relation to the environmental awareness and their willingness to take part in protecting the earth. In schools, the students learn to reveal their self-identity, to work together, to appreciate differences, to learn about responsibility and consequences, to learn to protect their environment, to grow the feeling of compassion not only to other individual but also to non-human living things, such as animals, plants, and nature. In relation to this, environmental education basically can be incorporated into English language class, either in foreign language (EFL) or second language (ESL) context. This is all because environmental issues are content-based and theme-based (Cates, 1990; Gürsoy, 2010; Gürsoy and Sağam, 2011).

To be able to participate in solving environmental problems requires critical thinking skills. As stated by Werner \& Bleich (2017), the ability to make decision and to take action cannot be separated from critical thinking skills. Geng (2014) states that the nature of critical thinking skills covers making judgement, making argument, questioning, processing information, solving a problem, disposition, and meta-cognition skill. University students, in general, are required to be able to think critically, such as to criticize, analyze, draw conclusion, make inferences on particular issues (Rezaee \& Mubarak, 2018). One way to see how critical someone is can be seen from the writing. As stated by Dunn \& Smith (2009), the activity of expressing one's thought in writing is a form of critical thinking. In writing, one is required 
to integrate and execute various skills, such as making argument, making organization and planning, as well as selecting appropriate grammar and punctuation rules. Thus, writing is typically seen as a way to enhance the critical thinking ability (Quitadamo \& Kurtz, 2007). With various environmental problems people face nowadays, the need to incorporate environmental issues in classroom teaching is becoming more and more urgent. Bringing the world into the classroom will force the students to think critically to find ways to solve the problems.

Studies on the use of environmental topics for EFL writing has been conducted in recent years. Setyowati \& Widiati (2014) propose activities that language teachers can use to incorporate environmental issues in Genre-Based Approach (GBA) for teaching different types of texts. Another study was conducted by Fauzan (2015) who investigates the attitudes and awareness of secondary school students in Central Kalimantan about environmental issues and their proposed solutions toward the problem. The finding shows that the students have poor environmental knowledge and awareness, and do not take any action to prevent the environmental damage that might happen. The study suggests that there should be instructional materials which will enrich the students' knowledge about environmental conservation. The current study aims to find out the students' ability in writing an essay by using environmental topic related to the use of water.

\section{LITERATURE REVIEWS}

\section{The Essay Elements}

An essay has three main elements, namely the introduction, the body, and the conclusion. Introduction is very important because it gives a frame to the body of the essay and provides context for the reader about the discussion that follows (Murray \& Murray (2012). The problem is, it is not easy to write a good introductory paragraph. To cope with this problem, there are several strategies to make the readers 'hooked' to read the essay, which is called 'hook strategies' or the "reference points" (Murray \& Murray, 2012). To hook the readers, the writer can use general background information, question, description, quotation, facts/statistics and anecdote (The writing center, in press).

The second element of an essay is the body. The body of the essay is the main part of the writing itself. The body presents and develops the main ideas (Murray \& Murray, 2012). The body is the part where the ideas are explored, explained, and given details. The last part of an essay is the conclusion. Writing a concluding paragraph for an essay is necessary. As stated by Zemach \& Islam (2004), a conclusion does not need to state a completely new idea. A conclusion may restate the topic, summarize the main idea, make prediction related to the topic being discussed, and make suggestions or advices connected to the topic. Murray \& Murray (2012) state that there is a difference between a conclusion and a summary. A summary is the restatement of the ideas with no new information being added. On the other hand, a conclusion presents new information to the reader which give general statement of the ideas being discussed.

\section{Research on Writing Elements}

Townsend, Hicks, Thomson, (1993) investigate to what degree the introduction and the conclusion affect the grade of the composition. The result of the study shows that the quality of the introduction gives more effect on the grading point undergraduate students' essay rather than the quality of the conclusion. Secondly, Umunnakwe \& Pitse (2017) investigate the students' ability in writing introductory paragraphs for academic writing in the University of Bostwana. The result reveals that the students face problems in making thesis statement and creating essay plan. They suggest that the writing teacher provide a step by step guidance through writing process to help the students improve the writing ability.

Within Indonesian context, some research has been done to investigate the students' ability in writing both in paragraph and essay form. Yunhadi (2016) investigates the undergraduate students' paragraph structure at University of Kutai Kertanegara. Through a content analysis design, he finds that not all students are aware of how to write a good and unified paragraph. The study reveals that the students have problems in writing a topic sentence, supporting sentences, and concluding sentence. Another study conducted by Qonitatun (2016) shows that the students ability in writing essay is poor even though they have experienced the sentence level writing class, paragraph writing class, and essay writing class. The result of her study also reveals that many of the essays made by the students do not have the conclusion, and the type of the sentences produced by the students is mostly simple sentences. The third study is conducted by Budiharso (2017) who develops a writing prompt and scoring rubric for argumentative essay. He finds that the development of writing prompt should be followed with the development of scoring rubric appropriate with the prompt. He argues that the descriptors of the rubric should refer to the characteristics of a good paragraph, namely the presence of topic sentence and controlling ideas, ideas development, and concluding sentences. For an essay, the rubric should focus on the introductory paragraph with its thesis statement, the development of the body of the paragraphs, and the concluding paragraph. 
Newer study is conducted by Alharbi (2019) who investigates the students' difficulties in writing a well-written paragraph for academic writing in EFL Saudian context. The result shows that the students have problems in using the mechanics such as spelling and punctuation, as well as the use of proper grammar, making topic sentences and supporting sentences. He further suggests that the writing course should be designed based on the students' challenges so that the best outcome can be realized.

\section{METHOD}

This study uses qualitative approach focusing on content analysis design. The typical instruments used to collect the data in content analysis design are interviews, observations, and document or artifact analysis (Hemphill, Richards, Templin, \& Blankenship, 2012). In this study, the researcher used document analysis. The researchers analyzed the students' composition with the topic related to the use of water. The data was collected on June 2019. The subjects of the study were 32 students of 2017 batch of STKIP PGRI Pasuruan in the academic year 2018-2019.

The data was analyzed qualitatively since the data was in the form of words, phrases, and sentences or non-numerical data. Data codification was used to help the researcher analyze the data. The students' writing was coded by using their initials, number of attendance list, part of sub analysis, and the class. The process of data analysis follows Miles \& Huberman's (1994) model, namely data collection, data display, data reduction, and conclusion drawing. Each of these steps was not done in a linear process, rather it was done simoultaneously. The students' essays were scored by two raters by using Jacobs ESL Composition Profile. This scoring rubric was used because it has been used by many researchers and practitioners in EFL and ESL context either in its original form or its adaptation form (Janssen, Meier, \& Trace, 2015). The raters were the English lecturers in the institution who had been teaching writing for approximately five years. Finally, to find out the students level in writing, the researchers decided to use the institution standard which ranged from excellent to very poor.

\section{FINDINGS AND DISCUSSION}

Students' Ability in Writing Essay by using Environmental Topic

The raters scored the students' composition by using Jacobs ESL Composition Profile, which covers content, organization, vocabulary, language, and mechanic. The scores between rater 1 and rater 2 were checked by using a statistical tool for its consistency. The result of correlational analysis shows a significant correlation between rater 1 and rater $2(0.02<0.05)$. This shows that there is an inter-rater reliability among raters. Having the evidence of inter-rater reliability, the scores between rater 1 and rater 2 then summed up and averaged. The average scores between rater 1 and rater 2 was used to decide the students' level based on the institution standard.

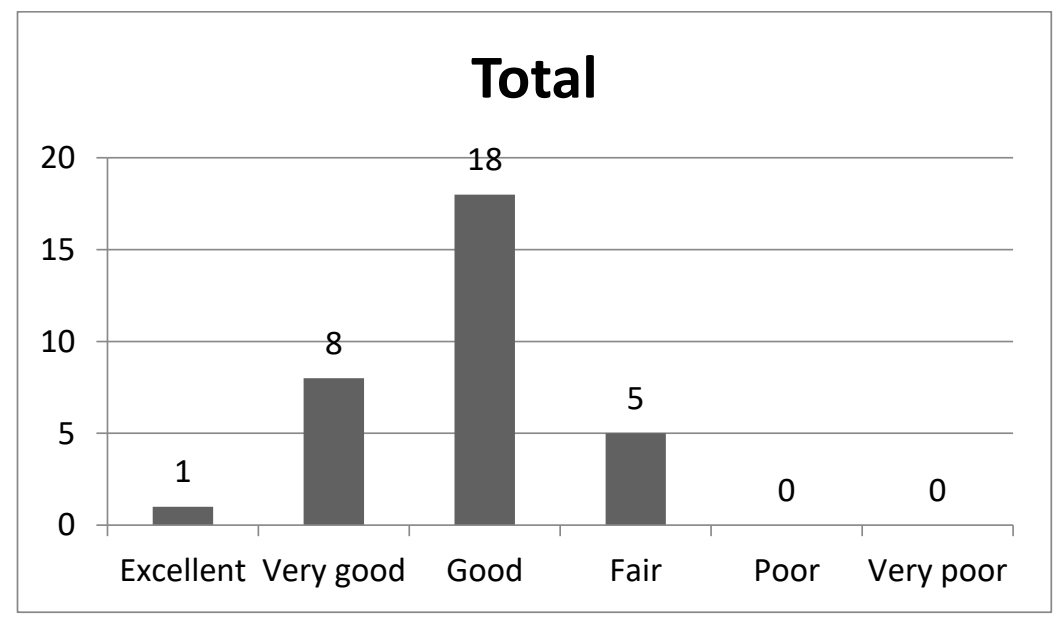

Figure 1. Overall Students' Ability

Figure 1 shows the overall students' ability in writing essay by using environmental topic. It can be seen that only one student $(3 \%)$ was able to reach the excellent level based on the institution standard, 8 students $(25 \%)$ reached very good level, 18 students $(56 \%)$ were in good level, and 5 students $(16 \%)$ were in fair level. It can be concluded that overall, the students were able to write essays about an environmental topic well. 
The Students' Ability to Write Introductory Paragraph

Overall, the students were able to make introduction for their essay. The type of introduction that they mostly preferred was general information (59\%) while other preferred question type (19\%) and facts and statistics (16\%).

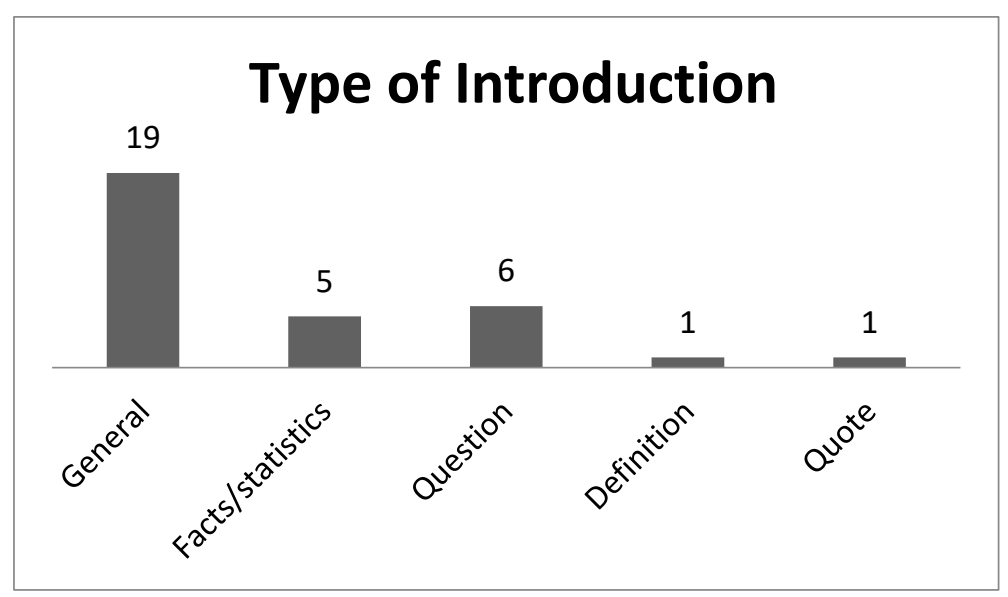

Figure 2. Type of Introduction the Students Used

One student preferred to use definition to open the introductory paragraph and another one used quotation to start the introductory paragraph.

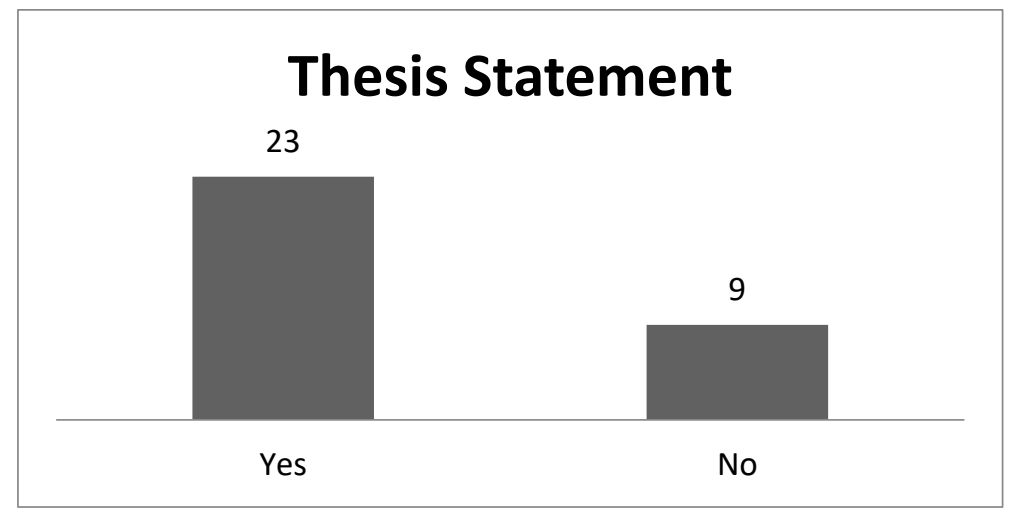

Figure 3. The Presence of Thesis Statement

The data also reveal that $72 \%$ of the students were able to state their thesis in the introductory paragraphs, while $28 \%$ of them were unable to state the thesis. The following is the example of one of the introductory paragraph written by the students.

Water is one of the earth materials which becomes a basic necessity for all living things on this earth. Not only humans, but animals and plants also need water to survive. Earth surface consists of $71 \%$ water. As much as $96.5 \%$ of all the earth's water is salt water contained within the oceans. While the remaining of $3.5 \%$ is fresh water contained in lakes and frozen water which is locked up in glaciers and the polar ice caps. Because the role of water is so vital for life, we are obliged to maintain and conserve water so that the water does not run out in the future. I have some reasons why we should be very economical on the use of water. (Data 13/LLS/043/Int/2017b)

Data 13 shows how the student starts the introductory paragraph. She opens the paragraph by using facts and statistics describing and comparing the number of fresh water and the salt water on earth. Her thesis statement occurs at the end of the introductory paragraph saying "I have some reasons why we should be very economical on the use of water." From the thesis statement, the reader can predict what she would write in the body of the essay, namely "the reasons".

\section{The Body of the Essay}

Half of the total number of the students produced two paragraphs in the body of the essay, while the other half wrote one long paragraph in the body of the essay. The shortest paragraph in the body 
consists of five complex sentences, while the longest paragraph in the body consists of 10 compound sentences.

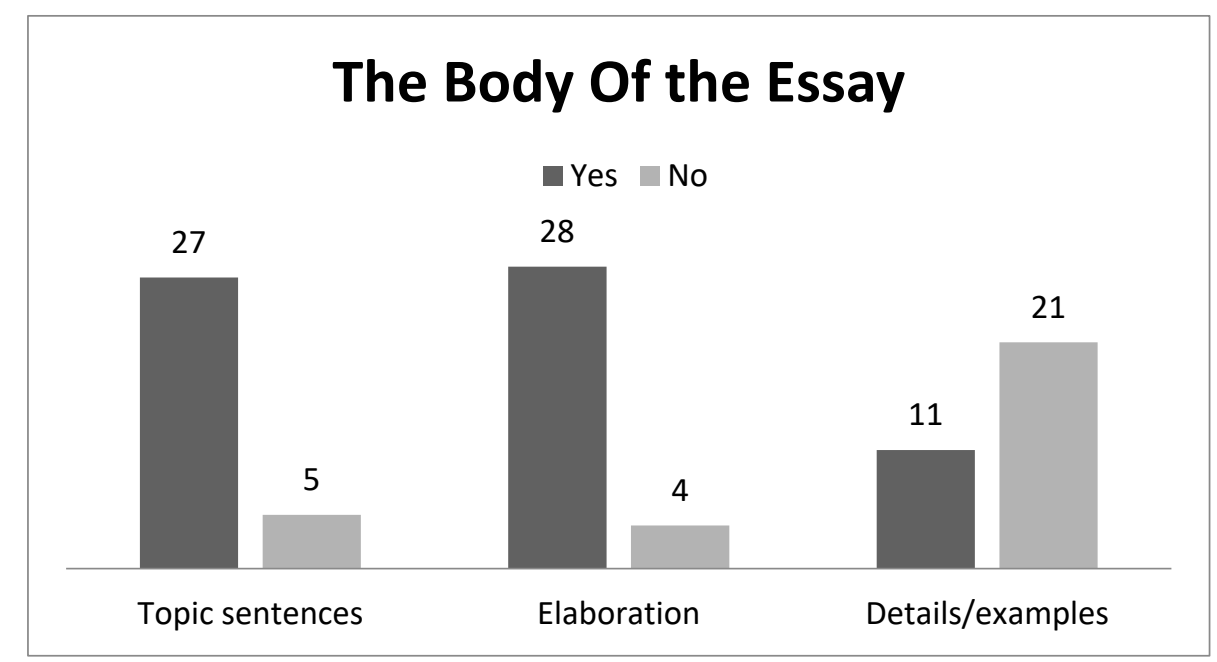

Figure 4. Description the body of the Essay

Figure 4 shows the students' ability in developing the body of the essay. The data shows that $84 \%$ of the students (27 students) were able to make topic sentence in the body of the paragraph, while $16 \%$ (5 students) had no topic sentence. In terms of the elaboration, $88 \%$ of the students (28 students) were able to give explanation and elaboration about the topic sentence they wrote, but $66 \%(21$ students) were not able to give details and examples from the elaboration. Thus, it can be concluded that only $34 \%$ ( 11 students) were able to make appropriate body of the essay. The students who belonged to this category were able to state the topic sentence (s) in the body of the essay, elaborated them, and gave sufficient details and examples to strengthen their opinion. The following is a sample of one of the students' work.

Indonesia has rich resources of water, but a number of areas in Indonesia is often hit by clean water crisis. According to the WaterAid in 2016, Indonesia is in the list of countries with the highest population who cannot access clean water. Indonesia is ranked 6th out of 10th countries. There are around 32 million people in the country living without clean water. For example, East Nusa Tenggara is an area that is always lack of water. Similarly, some small islands in Indonesia often have difficulties to get a source of clean water. In fact, they have to get water from rain water. So, we have to be very economical on the use of water so that it can be used by the next generation. One way that we can do to save water is by not polluting water. (Data 14/MA/019/Body/2017a).

Data 14 shows that the development of the body of the essay. The topic sentence which shows the first reason why the writer needs to be economical is stated in the first sentence....."Indonesia is often hit by clean water crisis". The student gives elaboration of the topic by giving the position of Indonesia in the world's rank in terms of the difficulty of accessing clean water and gives specific detail of which part of Indonesia suffered from clean water crisis.

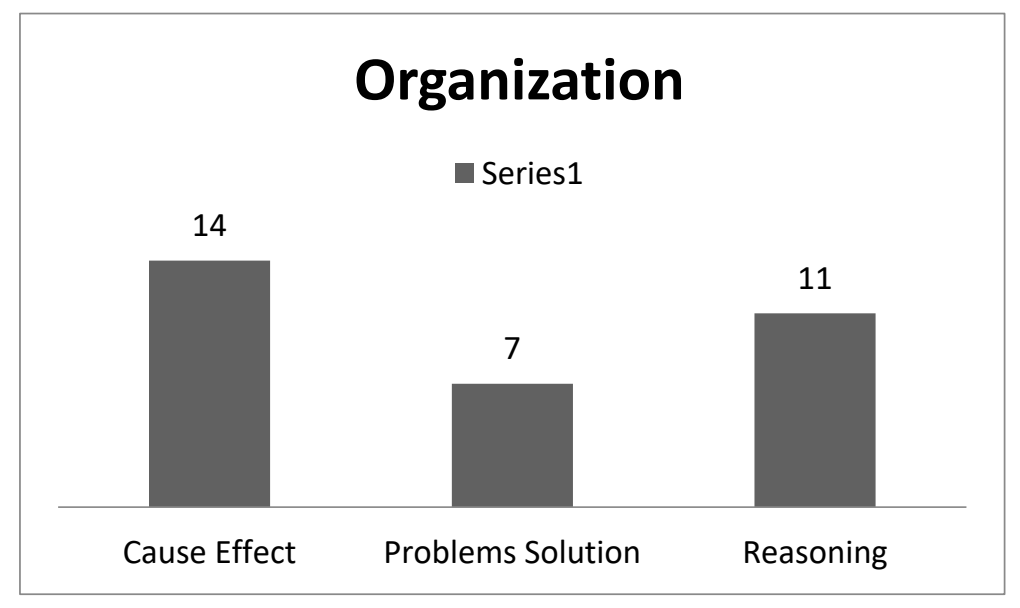

Figure 5. The paragraph organization 
The analysis of the body paragraph also reveals how the students organize their idea. The data analysis shows that $43 \%$ of the subjects (14 students) use cause and effect to develop the body of the essay, $22 \%$ (7 students) use problems solution, while the rest of them (11 students) use reasoning only.

\section{Making Conclusion}

All of the essays written by the students are completed with the conclusion. However, not all of them were able to write proper conclusion. The shortest conclusion made by the students was written in two compound sentences.

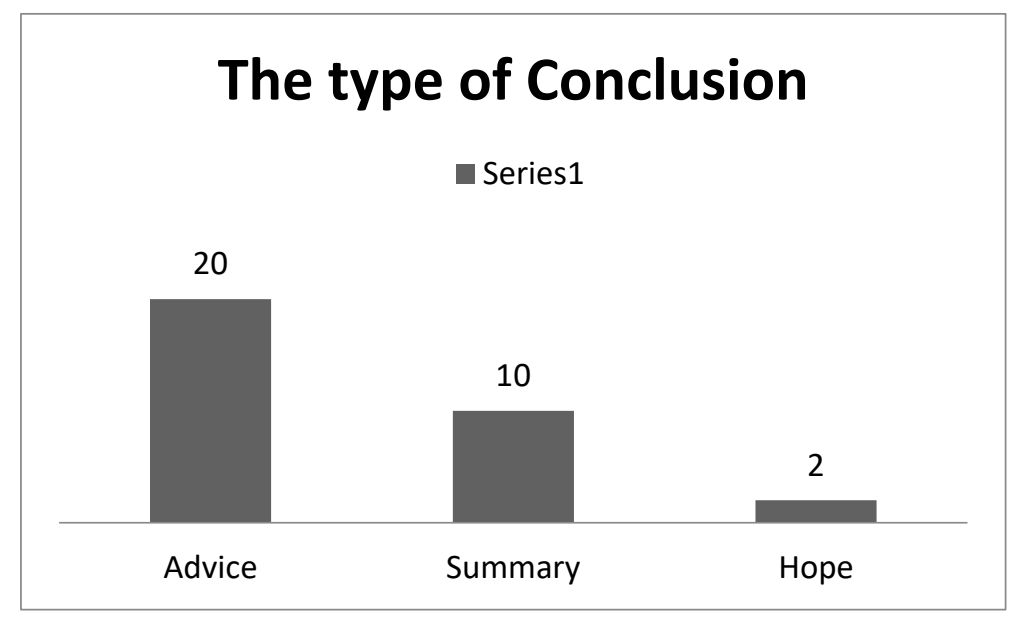

Figure 6. The type of conclusion Made by the Students

Figure 6 shows the type of the conclusion made by the students. From the total number of the students, $62 \%$ (20 students) close the essay by giving recommendation/advice to the reader, $31 \%$ (10 students) give summary, and the rest of them express hope for the future. The example of one the students' conclusion written for the essay can be seen in data 02.

In conclusion, water is our crucial need on this earth. Not only for us, water is also important for all organism, such as animals, trees, and so on. We do need water, especially the fresh water to keep us alive. So, we must save water. We must use it properly and economically in order to save the quantity and the quality of the fresh water in the future. (Data 02/MZ/002/Con/2017a)

Data 02 shows how the student closes the essay. The students in data 02 uses advice in the conclusion. The writer advices the audience (the reader) to save water and use it economically. The conclusion used by the student, as shown in data 02, is suitable with the topic of the essay.

As a conclusion, the role of water is vital for our life. And the clean water still remains about $3.5 \%$ in this world. It means that we have to conserve water use so that the future of this world is still maintained. What should we do? Let's save water to minimize the effect of drought and lack of water in the future by doing reuse the water, turn off the tap when tub is full, also minimize the use of plastic bottles. And we should preserve our environment by doing reduce, reuse, and recycle of water use. We should not throw garbage into toilets to avoid water pollution. (Data 13/LLS/043P/Con/2017b)

Data 13 shows that the student closes the essay by using summary and give recommendation for the reader. The first four lines of the conclusion is the summary of the essay, while the rest of the lines are the suggestion or advice for the reader to follow.

Based on the presentation of the data, it can be seen that the students in general are able to make an essay by using environmental topic. However, not all students in the present study belongs to the proficient writers. As stated by Indah (2017), a proficient writer have the ability to develop a knowledgeable topic, logically sequence the idea, express meaning in appropriate diction, construct sentences and use correct writing conventions. Looking at these criteria, only nine students (out of 32 students) can be categorized into skillful writers. Yet, even though not all students belong to the proficient and skillful writers, their writing has reflected their critical thinking skills, especially when they were asked to respond what they would do to save the water. The students' critical thinking skills are reflected on their analysis in terms of why water should be used wisely, the effect if water no longer exists, and the solutions to overcome the problems. 
The students' ability in expressing their ideas on their writing is understandable. It is all because the topic is familiar for them, since the use of water for daily life is familiar for the students. Research has shown that there is significant correlation between topic familiarity and students' writing performance (Indah, 2017). Her research shows that the more familiar the students with the topic initiated by the teacher, the better the students' writing performance will be. Furthermore, her study also reveals that there is a strong and positive correlation between writing and students' critical thinking on the topic initiated by the teacher. Her research indicates that the higher the students' writing performance when they produced composition based on the teacher's topic, the more critical thinking skills are reflected in the composition.

Based on the data, all students have introductory paragraph in their essay. A good introductory paragraph is the one which has the statement of the thesis in it (Murray \& Murray, 2012). Having a thesis statement in an essay is very important since it helps them to navigate the essay. As stated by Umunnakwe \& Pitse (2017) a thesis statement gives the writer a focus and direction of where to go or what to write in the rest of the essay. Most of the students $(72 \%$ of them) have the thesis statement in their essay even though the rest of them do not have one. The students' composition which has no thesis statement tend to have no focus. In fact, their composition cannot be considered a final product because the ideas are still scattered and incoherent. Thus, it is true when Murray \& Murray (2012) state that the thesis statement provides a frame for the writer. Meanwhile, the students' way to open the essay vary from giving general information about the topic, giving facts and statistics, making questions, giving definition and using quotation. Providing general information in the introductory paragraph becomes the favorite for the students, because they can start with a sentence like "water is very important for us" or "water is needed not only for human, but also for all organism." Those are the most common sentences that come up in the writer's mind to start the essay. Yet, a well-structured introduction is the one that puts the essay in context and is powerful enough to grab the readers' attention to read on (Umunnakwe \& Pitse, 2017).

In this study, the students developed the body of the essay by using cause effect relation, problem solution, and reasoning organization. Although many of them $(88 \%)$ have topic sentences in the developmental paragraphs and the elaboration of the topic through explanation, only $66 \%$ are able to provide details and examples to support the topic sentence. Developing the body of the essays by giving sufficient details and examples seem to be common problem for EFL learners. Qonitatun (2016) also find similar finding in terms of the developmental paragraphs. She finds out that the subjects of her study fail to develop the paragraphs for the essay well.

In terms of the concluding paragraph, all students manage to end the essays with a conclusion. Yet, not all of them are able to make a proper one. Making a concluding paragraph for an essay often become a problem for EFL learners (Qonitatun, 2016) as shown in her research. A concluding paragraph is an important part of an academic essay. It ends the writing and gives information to the reader about the writer's final thoughts. If one has a problem how to end the essay, he or she can use several strategies as proposes by Zemach \& Islam (2004: 29), namely restating the topic, summarizing the main idea, making prediction related to the topic being discussed, and making suggestions or advices connected to the topic. Similarly, according to Oshima \& Hogue (1997) the concluding paragraph may restate the thesis in different word or summarize the reasons as well as give the final thoughts or comment to call for action. In this present study, most of the concluding paragraph made by the students are giving advice or to call for action to save water. This type of concluding paragraph is considered appropriate as it is related to the topic being discussed.

\section{CONCLUSIONS AND SUGGESTIONS}

The teaching of language skills, especially writing, should incorporate global issues so that the students can have awareness and care about their surroundings. The goal of writing courses should shift from learning- to- write to writing-to-learn. In writing-to-learn activity, the students would learn how to think creatively and critically. The result of the present study shows that the use of environmental issue can trigger the students critical thinking skill as shown from their analysis as expressed in the body of their essay and the advice/recommendation they give in the conclusion. Yet, the result of the present study also implies that the students still have problems in developing the body of the essay as many of them are still struggling in providing details and examples to support the idea.

Some suggestions are given to the writing lecturers and future researchers. Firstly, it is suggested that the writing lecturers incorporate the global issues in the instructional material for the teaching of writing, such as poverty, gender equality, environmental issues, child labor, human trafficking, hunger, bullying, racism, terrorism, prejudice in the topic of academic writing. These topics would be eye-opening for the students because they happen in real life. Secondly, the future researchers need to investigate the use of environmental issue and how it relates to students' environmental awareness by using correlational design. Future researchers can also investigate the 
causal relationship between the use of environmental topics and the students' writing achievement by using experimental design. Having the information about the effectiveness of instructional materials which incorporates these types of issue would help the lecturers and practitioners to decide the effective way of teaching writing while at the same time enhancing the students critical thinking skills.

Acknowledgements

This research is funded by Directorate of Higher Education (DIKTI) 2019, under contract number 1499.i/STKIP/KS/IV/2019.

\section{REFERENCES}

Alharbi, M. A. (2019). EFL university students' voice on challenges and solution in learning academic writing. Indonesian Journal of Applied Linguistics, 8(3), 576-587. https://doi.org/10.17509/ijal.v8i3.15276

Budiharso, T. (2017). Developing prompts of argumentative essay writing for EFL college students. Indonesian Journal of Language Teaching and Linguistics, 2(3), 227.

Cates, K. 1990. Teaching for a better world: Global issues in language education. The Language Teacher 14: 3-5.

Dunn, D. S., \& Smith, R. A. (2009). Writing as Critical Thinking. In Teaching Critical Thinking in Psychology: A Handbook of Best Practices (pp. 161-173).

Fauzan, A. (2015). EFL students' awareness and attitudes on environmental issues and its educational solution. Journal on English as a Foreign Language, 3(2), 77.

Geng, F. (2014). An content analysis of the definition of critical thinking. Asian Social Science, 10(19), 124-128.

Gürsoy, E. (2010). Implementing environmental education to foreign language teaching to young learners. Educational Research, 1, (8), 232-238.

Gürsoy, Esim and Gülderen T. Sağlam. (2011). ELT Teacher Trainees' Attitudes Towards Environmental Education And Their Tendency To Use It In The Language Classroom. Journal of International Education Research 7, 4: 47-52.

Hemphill, M. A., Richards, K. A. R., Templin, T. J., \& Blankenship, B. T. (2012). A content analysis of qualitative research in the journal of teaching in physical education from 1998 to 2008. Journal of Teaching in Physical Education, 31(3), 279-287.

Indah, R. N. (2017). Critical Thinking, Writing Performance and Topic Familiarity of Indonesian EFL Learners. Journal of Language Teaching and Research, 8(2), 229.

Janssen, G., Meier, V., \& Trace, J. (2015). Building a better rubric: Mixed methods rubric revision. Assessing Writing.

Miles, M. A., Huberman, M. B. (1994). Miles and Huberman (1994)- Chapter 4.pdf. In Qualitative Data Analysis: An Expanded Sourcebook (pp. 50-72).

Murray, N., \& Murray, N. (2012). Writing an introduction. In Writing Essays in English Language and Linguistics (pp. 89-99).

Oshima, A., \& Hogue, A. (1997). Introduction to Academic Writing. Agenda, 223.

Qonitatun, Q. (2016). The Quality of Essay Writing of Indonesian EFL Learners. ASIAN TEFL Journal of Language Teaching and Applied Linguistics, 1(1).

Quitadamo, I. J., \& Kurtz, M. J. (2007). Learning to improve: Using writing to increase critical thinking performance in general education biology. CBE Life Sciences Education, 6(2), 140-154.

Rezaee, A. A., \& Mubarak, L. (2018). EFL learners' proficiency level and critical thinking: The case of Iraqi university students. International Journal of Language Studies, 12(3), 91-108.

Setyowati, L., \& Widiati, U. (2014). Integrating Environmental Education into a Genre-Based EFL Writing Class. English Teaching Forum, 52(4), 20-27.

Townsend, M. A. R., Hicks, L., Thompson, J. D. M., Wilton, K. M., Tuck, B. F., \& Moore, D. W. (1993). Effects of Introductions and Conclusions in Assessment of Student Essays. Journal of Educational Psychology, 85(4), 670-678.

Umunnakwe, N., \& Pitse, B. G. (2017). What is in the Essay? An Investigation of the Introductory Paragraph of Students' Academic Essays. International Journal of Scientific and Education Research, 1(1). Werner, S. H., \& Bleich, M. R. (2017). Critical thinking as a leadership attribute. Journal of Continuing Education in Nursing, 48(1), 9-11. 
Yunhadi, W. (2016). The Structural Parts of Paragraph Writing by Indonesian EFL Learners. International Journal of EFL, 1(1), 33.

Zemach, Dorothy \& Islam, Carlos . (2004). Paragraph Writing: From Sentence to Paragraph (1st Ed). Macmillan Education 


\section{APPENDIX}

Sample of the student's writing

\section{Conserving Water}

Water is one of the earth materials which becomes a basic necessity for all living things on this earth. Not only humans, but animals and plants also need water to survive. Earth surface consists of $71 \%$ water. As much as $96.5 \%$ of all the earth's water is salt water contained within the oceans. While the remaining of $3.5 \%$ is fresh water contained in lakes and frozen water which is locked up in glaciers and the polar ice caps. Because the role of water is so vital for life, we are obliged to maintain and conserve water so that the water does not run out in the future. I have some reasons why we should be very economical on the use of water.

The first reason is save water can minimize the effects of drought and lack of water. By reducing the amount of water that we use, we can better help face times of drought in the future. For example, we can turn off the tap when the tub is already full. Besides that, we can also use left over water to wash fruits and vegetables to water the plants. It means that we can reuse the water. And we can avoid using plastic bottles. Why? Because, besides being considered inefficient, the use of plastic bottles will damage water sources in the soil. Plastic bottles are very difficult and long to decompose in the soil. Besides that, the toxins that contained in plastic bottles will contaminate the soil and the existing water sources.

Another reasons is it will help preserve our environment. Reducing water use can reduce the energy needed to process and delivere it to homes, agriculture, factories, and society, which it turns helps reduce pollution and save fuel. Another way is not to throw garbage inthe toilet. Items that cannot be recycled, such as diapers, wet wipes, and plastic tampons can cause problems in the sewer system. These items will eventually end up in local tributaries, rivers, and other water wateer reservoirs that can endanger fish and wildlife. Instead of throwing in in the toilet, we should throw it in the trash can.

As a conclusion, the role of water is vital for our life. And the clean water still remains about $3.5 \%$ in this world. It means that we have to conserve water use so that the future of this world is still maintained. What should we do? Let's save water to minimize the effect of drought and lack of water in the future by doing reuse the water, turn off the tap when tub is full, also minimize the use of plastic bottles. And we should preserve our environment by doing reduce, reuse, and recycle of water use. We should not throw garbage into toilets to avoid water pollution. (Data 13/LLS/043P/2017b) 